\title{
Trajektorie vývoje mokřadů v horní části povodí Výrovky za uplynulých 180 let
}

\section{PAVEL RICHTER}

Klíčová slova: archivní mapy - mokřady - GIS - krajinné změny - voda v krajině - zemědělské hospodaření

\section{SOUHRN}

V tomto článku byla analyzována změna pokrytí mokřadů a zastoupení různých kategorií mokřadů za uplynulých 180 let v horní části povodí Výrovky. Jako podklady byly použity historické mapy stabilního katastru, současná ortofotomapa a GIS vrstvy aktuální lokalizace a klasifikace různých typů krajinného pokryvu. Na základě studia dostupných podkladů byly klasifikovány tyto čtyřri typy mokřadů: mokré louky, mokré louky s dřevinami, bažiny a močály a podmáčené lesy. Podmáčené lesy se ale vyskytovaly pouze na současných mapových podkladech. Rozloha mokřadů dramaticky poklesla z 687,74 ha v letech 1838-1841 (7,53 \% plochy řešeného území) na 9,29 ha v roce 2019 (0,1%). Zatímco převážnou část rozlohy historických mokřadů tvořily mokré louky (98,82 \%), v současnosti zaujímají největší plochu mokřadů vedle mokrých luk také podmáčené lesy (40,23\%, resp. 42,10\%). Polovinu plochy zmizelých mokřadů zaujala orná pưda, proto Ize sledované změny přičíst na vrub zejména zvyšování produkce zemědělské výroby. Zjištěné informace Ize využít při plánování krajiny s ohledem na ochranu a management mokřadů.

\section{ÚVOD}

Hlavním cílem výzkumu prezentovaného v tomto článku je analýza a hodnocení dlouhodobých změn mokřadních biotopů na krajinné úrovni. Jako pilotní území byla vybrána k. ú. na horním toku Výrovky v povodí Labe. Byly zde řešeny tyto hlavní výzkumné otázky:

- Jaká je dynamika změn (vyjádřená zastoupením kontinuálních, zmizelých a nových mokřadů) a trajektorie vývoje mokřadů na horním toku Výrovky?

- Jak se v průběhu historie měnila struktura zastoupení různých kategorií mokřadů?

V dalším období by mělo být zmapováno obdobným zpưsobem celé povodí Výrovky.

\section{STRUČNÝ SOUHRN METODIKY}

— Zájmová území byla vymezena jako katastrální území (k. ú.) patrící do horní části povodí III. rádu 1-04-06 Výrovka.

- Katastrální území byla lokalizována tak, aby tvořila souvislé území od pramene Výrovky v horní části povodí III. řádu 1-04-06 od nejvyšších partií povodí do 300 m n. m.
- Jako hlavní podklady byly použity archivní mapy stabilního katastru a současná ortofotomapa ČR. Archivní mapy byly georeferencovány a poté byly podklady vektorizovány.

- Prostorové změny byly zjištěny pomocí analýzy v prostředí GIS za pomoci nástrojü Symetrical difference a Intersection. Výsledkem je kategorizace mokřadů na segmenty kontinuální, zmizelé a nové.

- Dále byly u jednotlivých kategorií mokřadů popsány trajektorie jejich změn.

\section{VYMEZENÍ ÚZEMÍ}

Vymezené území leží v povodí Výrovky (povodí III. rádu 1-04-06), v mírně zvlněné, částečně zalesněné planině klesající pozvolna do Polabské nížiny (obr. 1). Převážná část řešeného území patří podle rámcového typu prírodní krajiny do mírně teplých krajin pánví a pahorkatin a část do mírně chladné krajiny pahorkatin a vrchovin a do teplé krajiny nížin, podle funkčních typů krajiny pak do krajiny polní a krajiny lesně-polní [1] v rozmezí 300-555 m n. m. Dominující půdní typy jsou hnědozem, kambizem kyselá a luvizem pseudoglejová. Toto území bylo vymezeno pomocí hranic současných k. ú. zároveň hranicemi povodí III. rádu. Bylo vybráno celkem 24 k. ú. o souhrnné rozloze 101,024km², z čehož 91,372 km² patří do povodí III. řádu 1-04-06 Výrovka, a tvoří tak řešené území (obr. 1 a 2). Povodí Výrovky bylo zvoleno proto, že se nachází na rozvodí dílčích povodí Dolní Vltava a Horní a střední Labe, přičemž se rozprostírá v rozmezí 175-555 m n. m. v celkem pěti typech krajiny ČR podle Romportla [1], a je tudiž vhodná k analýzám vývoje krajiny podle většího počtu krajinných typů. Tato krajina doznala intenzivních změn, kde byly mokřady vesměs přeměněny na jiné typy využití krajiny. V této krajině zároveň mokřady do velké míry chybí a jsou zde významné z důvodu zlepšení vodního režimu v krajině, zejména zmírnění dopadů záplav a déletrvajících suchých období.

Řešené území tvoři následující k. ú.: Bečváry, Církvice u Kolína, Doubravčany, Drahobudice, Hatě, Horní Jelčany, Hryzely, Chmeliště, Mančice u Rašovic, Nesměň u Zásmuk, Rašovice u Uhliřských Janovic, Sobočice, Uhlîrské Janovice, Vavřinec, Vršice, Zásmuky a Žišov celou rozlohou. Téměř celé k. ú. Bláto, Kochánov u Mitrova a Staňkovice u Uhlírských Janovic, zhruba polovina území k. ú. Janovická Lhota, Sudějov a Mitrov u Uhlírských Janovic a malá část k. ú. Opatovice II. [2].

Celé povodí III. řádu 1-04-06 Výrovka má rozlohu 543,045km² (rešené území tvoři tedy cca pětinu rozlohy tohoto povodí) a sousedí s těmito povodími III. raádu v dílčím povodí Horní a střední Labe: 1-04-01 Labe od Doubravy po Cidlinu, 1-04-04 Cidlina od Bystřice po ústí a Labe od Cidliny po Mrlinu, 1-04-05 Mrlina a Labe od Mrliny po Výrovku a 1-04-07 Labe od Výrovky po Jizeru. V dílčím povodí Dolní Vltavy je sousedním povodím III. rádu 1-09-03 Sázava od Želivky po ústí [3]. 


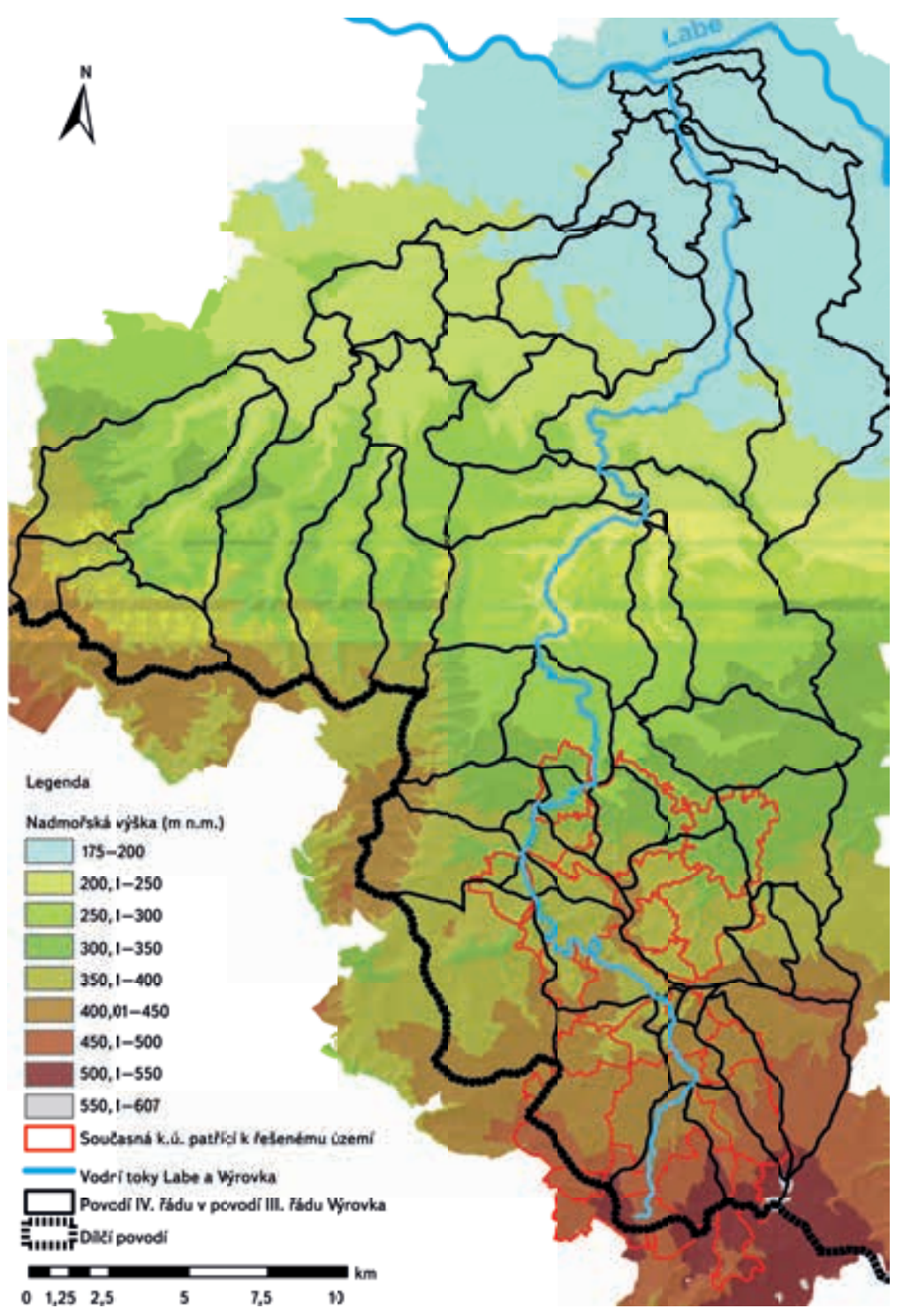

Obr. 1. Lokalizace řešeného území v rámci povodí III. rádu Výrovka; podkladová data ČÚZK [4] a DIBAVOD [7]

Fig. 1. Localization of the study area within of the Výrovka river basin; underlying data of ČÚZK [4] and DIBAVOD [7]

\section{MAPOVÉ POKLADY A JEJICH ZPRACOVÁNÍ}

\section{Historický stav krajiny a mokřadů}

Pro mapování historického stavu krajiny a mokřadů v polovině 19. století byly použity Císařské povinné otisky map stabilního katastru (SK), které jsou členěny podle tehdejších hranic katastrálních území. Byly mapovány v letech 1838 (Čáslavský kraj) a 1841 (Kouřimský kraj). Jsou k dispozici na webu Ústředního archivu zeměměřictví a katastru [2]. Jednotlivé mapové listy byly spojeny do celků podle př́slušnosti $\mathrm{k}$ historickému katastrálnímu území v grafickém programu Adobe Photoshop CS5.v12.

$\checkmark$ prípadě, že hranice historického a nového k. ú. nebyly totožné a část území nového k. ú. by chyběla, byla zpracována také příslušná část sousedního historického území. V řešeném území došlo $k$ těmto případům např. u k. ú. Rašovice (obr. 2), kde došlo ke změnám území se sousedními k. ú. Uhlírské Janovice,

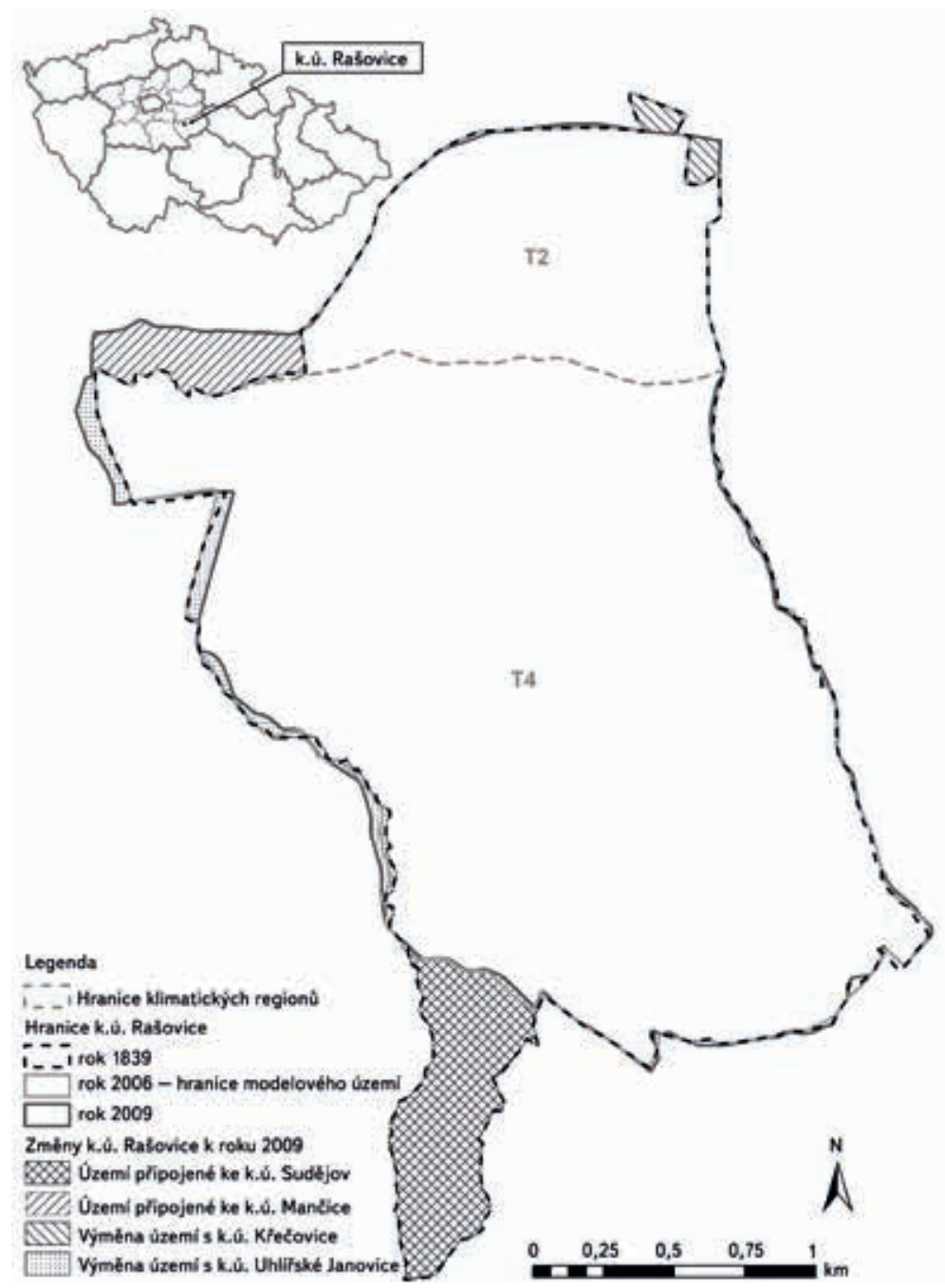

Obr. 2. Znázornění změn hranic k. ú. Rašovice [3]

Fig. 2. Image of boundaries changes of the Rašovice cadastral area [3]

Mančice a Sudějov [3]. Dále současné k. ú. Sudějov se rozprostírá také na části historického území k. ú. Žandov. Došlo k připojení podstatné části k. ú. Mitrov ke k. ú. Uhliřské Janovice a celé území současného k. ú. Bláto bylo historicky součástí k. ú. Staňkovice.

Takto zpracované podklady byly georeferencovány v souřadném systému S-JTSK East North pomocí nástroje Georeferencing v prostředí GIS, konkrétně v programu ArcMAP 10.7.1. Jako referenční vrstvy pro georeferencování byly použity vrstvy Základní mapy ČR v měř́tku 1: 10 000, současné hranice k. ú. a současná ortofotomapa. Všechny uvedené podklady byly připojeny pomocí WMS služby, která je k dispozici na Geoportálu ČÚZK [3].

Sledované kategorie mokřadů vycházejí z legendy map SK a byly definovány tak, aby bylo možné sledovat vývoj totožných kategorií jak na mapách SK, tak v současnosti. Jedná se o historické kategorie mokré louky, mokré louky s drévinami a bažiny a močály. Výjimku tvoři současná kategorii podmáčené lesy, které se na mapách SK nevyskytují. Obdobně byly klasifikovány také ostatní (nemokřadní) kategorie land use/cover. Jednalo se o ornou půdu, lesy, křoviny a dřeviny, louky a pastviny, zástavbu, komunikace, vodní plochy, vodní toky a sukcesní travnaté plochy na orné půdě, tj. plochy, většinou podmáčené, které již nebylo možno současným způsobem obdělávat a na jejich místě vznikaly povětšinou mokřadní anebo travinné biotopy ačkoli na všech podkladech byly dále vedeny jako orná půda, nicméně na základě současných i historických ortofotomap a terénního průzkumu byla určena tato kategorie. 


\section{Současný stav krajiny a mokřadů}

Typy využití území/krajinného pokryvu (land use/land cover) současné krajiny a stávající typy mokřadů byly identifikovány metodou manuální visuální intepretace s využitím kombinace několika různých typů podkladů. Hlavním zdrojem dat byla současná ortofotomapa, která je k dispozici na Geoportálu ČÚZK [4]. Pro verifikaci informací získaných z ortofotomapy byly využity následující dodatečné podklady:

- LPIS - pro určení typu zemědělských pozemků, k dispozici je vektorová vrstva na webu Veřejného registru pưdy [5];

- hranice porostní půdy - pro odlišení lesních porostů od nelesní drevinné vegetace, WMS služba je k dispozici na Geoportálu ÚHÚL [6], vrstva hranic porostní pưdy je převzata z Oblastních plánů rozvoje lesů;

— DIBAVOD - pro kontrolu lokalizace vodních toků a vodních nádrží a pro určení současných mokřadních biotopů byly použity vrstvy vodní toky, nádrže a bažiny a močály, které jsou dostupné na webových stránkách Digitální báze vodohospodářských dat [7]; vrstva bažiny a močály byla, podle dostupných metadat, aktualizována 6. 4. 2006, jako zdroj původních dat je uveden ZABAGED ${ }^{\oplus}$, tato vrstva byla verifikována na podkladě Základní mapy ČR v měřítku 1 : 10000 [3];

- při konfliktu vrstev Bažiny a močály z DIBAVOD [7], resp. Základní mapy ČR [4], a Hranice lesní půdy z ÚHÚL [6] byl jako způsob využití území/krajinného pokryvu (land use/cover) volen podmáčený les, prestože na historických mapových podkladech nebylo možné odlišit podmáčený les od ostatních typů lesa, nicméně při terénním průzkumu bylo zjištěno, že v těchto lokalitách se v řešeném území nachází lesní porost tvořený vlhkomilnými dřevinami (převážně olšinami), nikoli klasická bažina či močál.

\section{ANALÝZA PROSTOROVÝCH ZMĚN MOKŘADŮ NA ÚROVNI KRAJINY}

Prostorová analýza změn mokřadů na úrovni krajiny proběhla v prostředí GIS s využitím programu ArcMAP 10.7.1 za pomoci nástroje Symetrical difference pro tvorbu nových tříd prvků a prenos atributů na základě kombinací dvou překrývajících se tříd prvků a nástroje Intersection. Všechny krajinné segmenty byly interpretovány jako polygony, bez ohledu na to, zda jde o enklávy, nebo koridory v krajině [8], z důvodu nezbytnosti vytvoření výhradně polygonové vrstvy pro následné GIS prostorové analýzy. Výsledkem analýzy byla kategorizace mokřadů podle jejich časoprostorové dynamiky, a to na segmenty kontinuální, zmizelé a nové. Kategorie kontinuálních mokřadů znamená výskyt na stejné lokalitě jak na mapách stabilního katastru, tak v současnosti (podle DIBAVOD [7] a ortofotomapy [4] a při verifikaci dat také podle terénního průzkumu), zmizelé

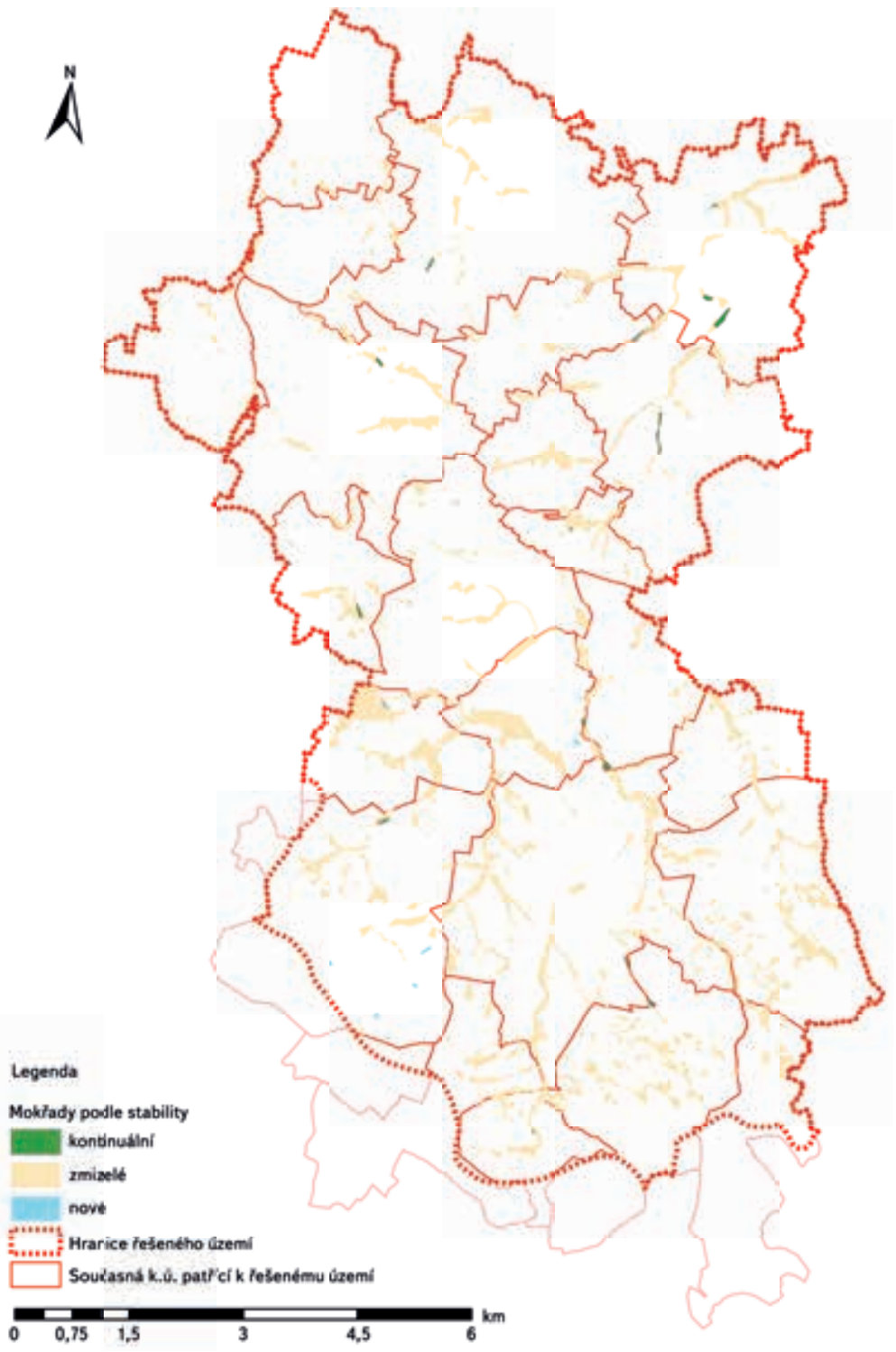

Obr. 3. Vývoj mokřadů v řešeném území, podkladová data ČúZK [4]

Fig. 3. Development of wetlands in the study area, underlying data of ČúZK [4]

mokřady jsou na dané lokalitě zaznamenány jen na mapách stabilního katastru a nové mokřady naopak jen na současných podkladech.

Tabulka 1. Změna rozlohy mokřadních ploch v řešeném území

Table 1. Change of wetlands in the study area

\begin{tabular}{|c|c|c|c|c|c|}
\hline \multirow{2}{*}{ Land use/cover } & \multicolumn{2}{|c|}{ Plocha (ha) } & \multicolumn{2}{|c|}{ Plocha (\%) } & \multirow{2}{*}{$\begin{array}{l}\text { Podíl ploch } \\
2019 \text { (\% z 1838/41) }\end{array}$} \\
\hline & $1838 / 41$ & 2019 & $1838 / 41$ & 2019 & \\
\hline mokré louky & 679,63 & 3,74 & 98,82 & 40,23 & 0,55 \\
\hline mokré louky s dřevinami & 7,34 & 1,64 & 1,07 & 17,67 & 22,36 \\
\hline bažiny, močály & 0,77 & - & 0,11 & - & - \\
\hline podmáčené lesy & - & 3,91 & - & 42,10 & - \\
\hline Celkem & 687,74 & 9,29 & 100,00 & 100,00 & 1,35 \\
\hline
\end{tabular}


Tabulka 2. Trajektorie změn rozlohy zmizelých mokřadů v řešeném území

Table 2. Trajectory of changes of the disappeared wetlands in the study area

\begin{tabular}{|c|c|c|c|}
\hline \multirow{2}{*}{ Typ změny } & \multirow{2}{*}{ ha } & \multicolumn{2}{|c|}{ Zastoupení } \\
\hline & & $\%$ typ & $\%$ \\
\hline mokré louky $\rightarrow$ orná půda & 338,24 & 50,19 & 49,63 \\
\hline mokré louky $\rightarrow$ louky a pastviny & 128,26 & 19,03 & 18,82 \\
\hline mokré louky $\rightarrow$ křoviny a dřeviny & 86,04 & 12,77 & 12,62 \\
\hline mokré louky $\rightarrow$ les & 60,42 & 8,96 & 8,87 \\
\hline mokré louky $\rightarrow$ zástavba & 33,27 & 4,94 & 4,88 \\
\hline mokré louky $\rightarrow$ vodní plochy & 13,52 & 2,01 & 1,98 \\
\hline $\begin{array}{l}\text { mokré louky } \rightarrow \text { sukcesní travnaté } \\
\text { plochy na orné půdě }\end{array}$ & 6,69 & 0,99 & 0,98 \\
\hline mokré louky $\rightarrow$ komunikace & 4,65 & 0,69 & 0,69 \\
\hline mokré louky $\rightarrow$ vodní toky & 2,87 & 0,42 & 0,42 \\
\hline Celkem & 673,96 & 100,00 & 98,89 \\
\hline $\begin{array}{l}\text { mokré louky } \\
\text { s dřevinami } \rightarrow \text { louky a pastviny }\end{array}$ & 2,86 & 42,08 & 0,42 \\
\hline $\begin{array}{l}\text { mokré louky } \\
\text { s dřevinami } \rightarrow \text { křoviny a dřeviny }\end{array}$ & 1,86 & 27,32 & 0,27 \\
\hline $\begin{array}{l}\text { mokré louky } \\
\text { s dřevinami } \rightarrow \text { zástavba }\end{array}$ & 1,70 & 25,07 & 0,25 \\
\hline $\begin{array}{l}\text { mokré louky } \\
\text { s dřevinami } \rightarrow \text { orná půda }\end{array}$ & 0,24 & 3,46 & 0,03 \\
\hline mokré louky s dřevinami $\rightarrow$ les & 0,13 & 2,07 & 0,02 \\
\hline Celkem & 6,79 & 100,00 & 0,99 \\
\hline bažiny a močály $\rightarrow$ vodní plochy & 0,31 & 40,39 & 0,046 \\
\hline $\begin{array}{l}\text { bažiny a močály } \rightarrow \text { louky } \\
\text { a pastviny }\end{array}$ & 0,18 & 23,66 & 0,030 \\
\hline bažiny a močály $\rightarrow$ zástavba & 0,10 & 12,29 & 0,016 \\
\hline bažiny a močály $\rightarrow$ orná půda & 0,08 & 10,72 & 0,014 \\
\hline $\begin{array}{l}\text { bažiny a močály } \rightarrow \text { křoviny } \\
\text { a dřeviny }\end{array}$ & 0,07 & 9,28 & 0,010 \\
\hline bažiny a močály $\rightarrow$ komunikace & 0,03 & 3,66 & 0,004 \\
\hline Celkem & 0,77 & 100,00 & 0,12 \\
\hline Celkem & 681,51 & - & 100,00 \\
\hline
\end{tabular}

Tabulka 3. Trajektorie změn rozlohy nových mokřadů v řešeném území Table 3. Trajectory of changes of the new wetlands in the study area

\begin{tabular}{|c|c|c|c|}
\hline \multirow{2}{*}{ Typ změny } & \multirow{2}{*}{ ha } & \multicolumn{2}{|c|}{ Zastoupení } \\
\hline & & $\%$ typ & $\%$ \\
\hline lesy $\rightarrow$ podmáčené lesy & 1,57 & 78,98 & 50,98 \\
\hline orná půda $\rightarrow$ podmáčené lesy & 0,41 & 21,02 & 13,56 \\
\hline Celkem & 1,98 & 100,00 & 64,54 \\
\hline $\begin{array}{l}\text { vodní plochy } \rightarrow \text { mokré louky } \\
\text { s dřevinami }\end{array}$ & 0,58 & 69,20 & 18,93 \\
\hline $\begin{array}{l}\text { louky a pastviny } \rightarrow \text { mokré louky } \\
\text { s dřevinami }\end{array}$ & 0,19 & 22,12 & 6,05 \\
\hline $\begin{array}{l}\text { orná půda } \rightarrow \text { mokré louky } \\
\text { s dřevinami }\end{array}$ & 0,05 & 6,30 & 1,72 \\
\hline $\begin{array}{l}\text { vodní toky } \rightarrow \text { mokré louky } \\
\text { s dřevinami }\end{array}$ & 0,02 & 2,38 & 0,66 \\
\hline Celkem & 0,84 & 100,00 & 27,36 \\
\hline orná půda $\rightarrow$ mokré louky & 0,17 & 67,07 & 5,43 \\
\hline vodní toky $\rightarrow$ mokré louky & 0,06 & 24,10 & 1,95 \\
\hline komunikace $\rightarrow$ mokré louky & 0,008 & 4,01 & 0,32 \\
\hline louky a pastviny $\rightarrow$ mokré louky & 0,006 & 2,41 & 0,20 \\
\hline vodní plochy $\rightarrow$ mokré louky & 0,006 & 2,41 & 0,20 \\
\hline Celkem & 0,25 & 100,00 & 8,10 \\
\hline Celkem & 3,07 & - & 100,00 \\
\hline
\end{tabular}

Tabulka 4. Trajektorie změn rozlohy kontinuálních mokřadů v řešeném území Table 4. Trajectory of changes of the continuous wetlands in the study area

\begin{tabular}{|c|c|c|c|}
\hline \multirow{2}{*}{ Typ změny } & \multirow{2}{*}{ ha } & \multicolumn{2}{|c|}{ Zastoupení } \\
\hline & & $\%$ typ & $\%$ \\
\hline mokré louky $\rightarrow$ mokré louky & 3,41 & 60,17 & 54,84 \\
\hline mokré louky $\rightarrow$ podmáčené lesy & 1,46 & 25,76 & 23,48 \\
\hline $\begin{array}{l}\text { mokré louky } \rightarrow \text { mokré louky } \\
\text { s dřevinami }\end{array}$ & 0,80 & 14,07 & 12,82 \\
\hline Celkem & 5,67 & 100,00 & 91,14 \\
\hline $\begin{array}{l}\text { mokré louky s dřevinami } \rightarrow \\
\text { podmáčené lesy }\end{array}$ & 0,47 & 85,84 & 7,60 \\
\hline $\begin{array}{l}\text { mokré louky s dřevinami } \rightarrow \\
\text { mokré louky }\end{array}$ & 0,077 & 13,61 & 1,21 \\
\hline $\begin{array}{l}\text { mokré louky s dřevinami } \rightarrow \\
\text { mokré louky s dřevinami }\end{array}$ & 0,003 & 0,55 & 0,05 \\
\hline Celkem & 0,55 & 100,00 & 8,86 \\
\hline Celkem & 6,22 & - & 100,00 \\
\hline
\end{tabular}




\section{VÝSLEDKY}

\section{Rozloha historických a současných mokřadů}

Historické mokřady jsou tvořeny součtem ploch mokřadů zmizelých a kontinuálních. V první polovině 19. století byla plocha mokřadů na řešeném území 687,74 ha, což predstavuje 7,52 \% rozlohy řešeného území. Naproti tomu v roce 2019 mokřady zaujímaly jen 9,29 ha, tj. pouze 0,1 \% rozlohy řešeného území. Celková rozloha mokřadů se tedy zmenšila zhruba pětasedmdesátkrát.

Podstatnou část rozlohy historických mokřadů $v$ řešeném území tvořily mokré louky, a to 679,63 ha (tj. 98,82 \% rozlohy historických mokřadů), následovaly mokré louky s dřevinami o ploše 7,34 ha (1,07\%). Zbytek rozlohy historických mokřadů, 0,77 ha (0,11 \%), připadal na bažiny a močály (tabulka 1).

Současné mokřady jsou tvořeny součtem ploch mokřadů nových a kontinuálních. V současnosti mezi mokřadními typy největší plochu zaujímají podmáčené lesy a mokré louky. Pokrývají 3,91 ha, resp. 3,74 ha (tj. 42,1 \%, resp. 40,23 \%). Zbytek rozlohy současných mokřadů, 1,07 ha (0,11\%), prripadal na mokré louky s drevinami. Klasické bažiny a močály z této krajiny vymizely (tabulka 1).

Na celém zájmovém území o souhrnné ploše 91,372 km² (24k. ú.) zmizelé mokřady zaujímaly plochu 681,51 ha, což je 99,1\% plochy historických mokřadů, kontinuálně se vyskytující mokřady pokrývají plochu 6,22 ha $(0,9 \%$ plochy historických mokřadů). Mokřady nové se rozkládají na ploše 3,07 ha, což je cca 220x méně než plocha zmizelých mokřadů (tabulky 2-4). Z těchto údajů je zřejmé, že převážná část plochy historických mokřadů z řešeného území zmizela a tato ztráta nebyla kompenzována vznikem mokřadů nových.

\section{Trajektorie změn mokřadů}

Naprostá většina mokřadů v řešeném území vymizela (681,51 ha, tj. 98,65 \%) (tabulka 2), kontinuální a nové mokřady tvoří pouze nepatrný zlomek plochy všech typů mokřadů podle stability (obr. 2). U kontinuálních se jedná o 6,22 ha $(0,9 \%)$ a u nových o 3,07 ha (0,45 \%) (tabulky 3 a 4).

Na místě zmizelých mokřadů je $v$ současnosti dominantním způsobem využití území orná půda, která tvoři 49,68 \% jejich původní plochy. Významný podíl zaujímají také louky a pastviny (19,27 \%) a křoviny a dřeviny (13,3\%). Les se rozprostírá na 8,89 \% a zástavba na 5,15 \% plochy původních mokřadů. Méně jsou zastoupeny vodní plochy. Komunikace a vodní toky zaujímají pouze nevýznamný podíl z plochy zmizelých mokřadů. Mokré louky se nejvíce změnily z 50,1 \% na ornou půdu. Bažiny s močály se změnily ze 40,39 \% na vodní plochy a ze 23,66 \% na louky a pastviny. Na místě mokrých luk s dřevinami se nejvíce vyskytují louky a pastviny (42,08 \%), křoviny a dřeviny (27,32 \%) a zástavba (25,07\%) (tabulka 2)

Nově vzniklé mokřady tvoři převážně podmáčené lesy (1,98 ha). Mokré louky a mokré louky s dřevinami se jako nové mokřady rozkládají na ploše 0,84 ha, resp. 0,25 ha. Nové mokřady se vyskytují převážně na místě bývalých lesů (50,98\%), orné půdy (20,71 \%) a vodních ploch (19,13 \%). Dále jsou významněji zastoupeny jen louky a pastviny (6,25\%). Minimálně jsou zastoupeny vodní toky a komunikace (tabulka 3).

U kontinuálních mokřadů tvoři v současnosti největší plochu mokré louky (4,29 ha). Plochu 1,93 ha zaujímají podmáčené lesy. Mokré louky s dřevinami tvoři plochu o rozloze 0,803 ha. Všechny typy kontinuálních mokřadů se nacházejí převážně na místě historických mokrých luk (tabulka 4).

\section{DISKUSE}

Výsledky dokládají zcela zásadní úbytek mokřadů v krajině řešeného území, kdy se z původní rozlohy v letech 1838-1843 zachovalo pouze 1,35 \% mokřadů. I s ohledem na analýzu prostorových změn mokřadů (tabulka 2), kdy polovinu zmizelých mokřadů zaujala orná půda, Ize sledované změny príicist na vrub zejména zvyšování produkce zemědělské výroby, což je $v$ souladu $s$ trendy vývoje land use v Českých zemích [9-11]. Zajímavá je i změna složení mokřadů zatímco $v$ 19. století dominovaly mokré louky ( $98,82 \%$, oproti 40,23 \% dnes), v současné krajině mírně převažuje kategorie podmáčené lesy (42,15\%) nad mokrými loukami (40,19\%). Důvodem je zřejmě fakt, že došlo ke změně funkce mokřadů - zatímco v minulosti plnily mokré louky do značné míry funkci produkční a byly využívány pro sklizeň sena nebo rákosu [12], a to nejen u nás, ale také v jiných zemích, např. ve Švédsku [13], v současnosti mokré louky přestaly být obdělávány a začaly zarůstat vlivem sukcese [12].

Tato práce je realizována formou prípadové studie, není souhrnně mapováno celé území ČR. Jelikož je rešené území dostatečně velké (24 k. ú., rozloha $91,372 \mathrm{~km}^{2}$ ), je zde předpoklad, že získané výsledky budou pro tento typ krajiny reprezentativní. Z hlediska metodiky bylo zajímavé zařazení kategorie podmáčených lesů k současným mokřadům, ačkoli na mapách SK se tato kategorie nevyskytuje. Nicméně pokud bychom tuto kategorii ponechali jako bažiny a močály, neodpovídalo by to skutečnosti, a pokud bychom ji ponechali jako les, zkreslilo by to plochu současných mokřadů. $V$ řešeném území takto bažiny a močály úplně vymizely, ale pokud bychom podmáčený les překvalifikovali, tak by bažiny a močály zaznamenaly nárưst na 512 \% z pưvodní plochy. Nicméně tato kategorie se vyskytuje převážně v k. ú. Staňkovice na území

Tabulka 5. Změna rozlohy mokřadních ploch v řešeném území při započítání rybníků Table 5. Change of wetlands in the study area, including ponds

\begin{tabular}{|c|c|c|c|c|c|}
\hline \multirow{2}{*}{ Land use/cover } & \multicolumn{2}{|c|}{ Plocha (ha) } & \multicolumn{2}{|c|}{ Plocha (\%) } & \multirow{2}{*}{$\begin{array}{l}\text { Podíl ploch } \\
2019(\% \text { z 1838/41) }\end{array}$} \\
\hline & $1838 / 41$ & 2019 & $1838 / 41$ & 2019 & \\
\hline mokré louky & 679,63 & 3,74 & 81,01 & 2,48 & 0,55 \\
\hline mokré louky s dřevinami & 7,34 & 1,64 & 0,87 & 1,09 & 22,36 \\
\hline bažiny, močály & 0,77 & - & 0,09 & - & - \\
\hline podmáčené lesy & - & 3,91 & - & 2,61 & - \\
\hline rybníky & 151,28 & 141,06 & 18,03 & 93,82 & 93,24 \\
\hline Celkem & 839,02 & 150,35 & 100,00 & 100,00 & 17,92 \\
\hline
\end{tabular}


Ratajské obory, kde je převážně smíšený les, bez velkých smrkových monokultur, který není postižen kưrovcovou kalamitou, a jedná se opravdu o vlhkomilné dřevinné porosty zapojené do okolního lesa. Podmáčené lesy se vyskytují jak na místě historického lesa (1,57 ha), tak na místě mokrých luk a mokrých luk s dřevinami (1,46 ha, resp. 0,47 ha), které byly obklopeny lesem. Zatímco na místě lesa se nedá určit, zda historicky již tyto lokality nebyly podmáčeny, na místě mokrých luk je zřejmé, že docházelo k zarůstání vlivem sukcese, protože mokré louky prestaly být hospodářsky využívány. Je předpoklad, že v dolní části povodí Výrovky se již současné bažiny a močály budou vyskytovat, jelikož tomu napovídají výsledky studií zabývajících se krajinou nížin [14, 15].

Rybníky jako typ mokřadů nebyly uvažovány. Jako mokřad byl určen pouze biotop s vegetačním pokryvem nikoli s otevřenou vodní hladinou. Z hlediska krajinně ekologického i vodohospodářského jsou rybníky řazeny mezi vodní plochy, nicméně zároveň splňují definici mokřadů [16]. Pokud bychom k mokřadům zařadily také rybníky, tak by se plocha historických mokřadů zvýšila z původních 687,74 ha (7,52 \% plochy řešeného území) na 839,02 ha (9,18 \%). Plocha současných mokřadů by pak činila 150,35 ha (1,64 \%), namísto 9,29 ha (0,1\%). Rybníky by zaujímaly $18 \%$ plochy historických mokřadů a mokré louky by stále byly dominantním typem historických mokřadů, ale namísto původních 98,82 \% by pokrývaly jen $81 \%$. Rybníky by také byly naprosto dominantním typem současných mokřadü, kde by tvorily 93,24 \%. Také by zařazení rybníků mezi mokřady způsobilo navýšení podílu plochy současných mokřadů na plochu historických mokřadů z 1,35 \% na $17,92 \%$. U historických mokřadů by zařazení rybníků nezpůsobilo výrazné změny ve výsledcích, zatímco u současných by byl rozdíl markantní (tabulka 5). Je to dáno velkým výskytem mokřadů v minulosti a jejich téměř úplným vymizením v současnosti. Nicméně v dolní části povodí Výrovky je předpoklad navýšení plochy zmizelých rybníků, protože rybníky byly zazemňovány kvůli úrodnějším pưdám v nížinách a zvyšujícímu se tlaku na zemědělskou produkci.

Za sledovanou dobu se několikrát změnilo správní členění. Zatímco v polovině 19. století patřilo sledované území částečně ke Kouřimskému a Čáslavskému kraji, v současnosti patří celé do Středočeského kraje, částečně do okresu Kutná Hora a okresu Kolín. Ačkoli jako řešené území je primárně počítáno celé povodí III. ráádu Výrovka, je praktičtější území zpracovávat podle jednotlivých k. ú., protože takto jsou distribuovány mapy SK a je jednodušší evidence zpracovaného, resp. nezpracovaného území.

Bylo by vhodné získané poznatky využít při plánování krajiny s ohledem na ochranu a management mokřadů, zvláště vzhledem k měnícím se klimatickým podmínkám. Evaporace ČR rychle roste, průměrná evaporace byla mezi lety 2001 a 2018 o 18 \% (519mm) vyšší než v letech 1971-2000 (440mm). Přičemž simulace budoucích scénárư pomocí regionálních klimatických modelů predpovídají růst až o 54 \%. Takový nárůst by měl vážné důsledky pro dostupnost povrchových vod a zemědělskou produkci v období sucha v ČR, jak se již prokázalo v období sucha 2014-2018 [17].

Také by se daly využít jako návod pro vypracování jednoho z podkladů pro zpracování plánů povodí 3. plánovacího období (2022-2027). Je důležité zlepšit zvláště ekologický stav vodních útvarů povrchových vod, jelikož za poslední hodnocené období 2016-2018 vychází v nevyhovujícím ekologickém stavu/ potenciálu 94,6 \% útvarů povrchových vod kategorie „řeka” a 86,3 \% útvarů kategorie "jezero" [18]. Některé složky hodnocení ekologického stavu/potenciálu, jako je zastoupení fytoplanktonu, makrozoobentosu, ryb, makrofyt nebo fytobentosu a dále nasycení vody kyslíkem, by bylo možné zvýšit príibližením stavu vodních toků tomu původnímu, tj. obnovou meandrů a přilehlých mokrých luk vhodných pro rozliv namísto zahloubených naprímených, často vydlážděných koryt. Zřejmě by bylo vhodné spustit $v$ rámci možností jakýsi reverzní proces $k$ tomu, co zde probíhalo ve druhé polovině minulého století (napřimování koryt, meliorace, likvidace remízků a mokřadů apod.). Jestliže mohlo být věnováno tak velké úsilí a tak mnoho finančních prostředků na výše uvedenou přeměnu naši krajiny, zřejmě bude nutné věnovat také velké úsilí a mnoho finančních prostředků na preměnu naší krajiny zpět blíže k původnímu stavu, kde krajina plnila mnohem lépe mimoprodukční funkce, zejména byla mnohem způsobilejší pro zadržování vody.

Možná že se v oblasti reakce na probíhající klimatickou změnu a s tím spojené udržitelné zemědělství blýská na lepší časy. Na začátku března 2020 byl zveřejněn dokument vyzývající k tomu, aby společná zemědělská politika EU (SZP) řešila také udržitelnost, podepsaný více než 3600 signatáři [19]. Zároveň byl publikován článek přibližující tuto výzvu a s ní spojenou problematiku. V zásadě šlo o to začít prosazovat udržitelnost zemědělství. V EU selhává SZP, zejména pokud jde o biologickou rozmanitost a degradaci půdy. Je zde vyzýván Evropský parlament, Rada a Komise, aby přijaly 10 naléhavých opatření pro zajištění udržitelné výroby potravin, zachování biologické rozmanitosti a zmírňování změny klimatu v oblasti SZP [20]. Tvưrci SZP na výzvu reagovali, ale nyní jsou zrejemě na pořadu dne jiná naléhavá témata týkající se epidemiologické situace. Zatím nezbývá než doufat, že v oblasti SZP dojde skutečně k prosazovaným změnám.

\section{ZÁVĚR}

Hlavními výsledky byly popis trajektorií vývoje mokřadních biotopů na horním toku Výrovky a ověření metodiky sledování vývoje mokřadư pro použití na celém povodí III. řádu Výrovka. Plocha mokřadů před polovinou 19. století byla na řešeném území 687,74 ha, zatímco v roce 2019 jen 9,29 ha (1,35 \% jejich původní rozlohy), což znamená dramatický úbytek mokřadů v krajině. Zmizelé mokřady v tomto území zaujímaly plochu 681,51 ha (98,65 \% plochy všech typů mokřadů podle stability), kontinuálních mokřadů je 6,22 ha (0,9 \%) a mokřady nové zaujímají plochu 3,07 ha (0,45 \%). Na místě zmizelých mokřadů je v současnosti nejdominantnějším land use/cover typem orná půda, tvoři 49,68 \% jejich plochy. Významný podíl zaujímají louky a pastviny a křoviny s dřevinami, je to 19,27 \%, resp. 13,3\%. Tyto skutečnosti potvrzují, že ve sledovaném území prevažují vlivem hospodaření v krajině zmizelé vývojové typy mokřadů a že mokřady byly převážně nahrazeny ornou půdou. Z toho vyplývá, že sledované změny lze přičíst na vrub predevším zvyšování produkce zemědělské výroby.

Tyto výsledky ukazují také, jak by měl vypadat jeden z důležitých podkladů pro obnovu mokřadů v krajině. Obnova mokřadů je v době současné klimatické změny nesmírně důležitá, avšak stále opomíjená. Tyto biotopy mají totiž velký polyfunkční význam v krajině. Zejména mají schopnost zadržovat vodu v období jejího přebytku a posléze v období sucha vodu uvolňovat (tzn. že fungují v krajině jako jakási houba). Kromě toho, že zmírňují dopady sucha a povodní, zlepšují kvalitu vody ve vodních tocích a redukují proces eroze.

Závěrem si dovolím apelovat na to, aby státní instituce při podpoře obnovy mokřadů zohledňovaly to, kde mokřady přirozeně byly a kde je pro ně vhodný terén. Hlavně tedy, aby se v „boji proti suchu“ konečně finančně podporovaly konkrétní změny, které přinesou zadržení vody v krajině a ne jen zprávy či studie, prípadně predikční modely pro předpověd’ vývoje sucha nebo výstavba dalších velkých přehrad, pro které už v současné době není ve vodních tocích dostatek vody apod. Pro vymezení mokřadů na současné zemědělské pưdě je nastaven vcelku jednoznačný legislativně a metodicky podpořený postup, včetně dotační politiky, který však není téměř vůbec využiván. 


\section{Literatura}

[1] ROMPORTL, D., CHUMAN, T. a LIPSKÝ, Z. Typologie současné krajiny Česka. Geografie, 2013, roč. 118, č. 1, s. 16-39.

[2] Archivní mapy Ústředního archivu zeměměřictví a katastru [online]. [cit. 15. zárí 2020]. Dostupné z: https://archivnimapy.cuzk.cz

[3] RICHTER, P. Analýza vývoje krajiny v zemědělských oblastech na př́kladu k. ú. Rašovice. Acta Pruhoniciana, 2011, 99, s. 29-39.

[4] Geoportál ČÚZK/ Prohlížecí služby - WMS [online]. [cit. 13. červenec 2020]. Dostupné z: https:// geoportal.cuzk.cz/(S(Icsguqwsq1my1rvbg3qy5suw))/Default.aspx?mode=TextMeta\&side=wms. verejne\&text=WMS.verejne.uvod\&head_tab=sekce-03-gp\&menu=311

[5] LPIS-Veřejný registr půdy [online]. [cit. 29. červenec 2020]. Dostupné z: http://eagri.cz/public/app/ lpisext/lpis/verejny2/plpis/ >

[6] Geoportál ÚHúL [online]. [cit. 30. červenec 2020]. Dostupné z: http://geoportal.uhul.cz/mapy/ MapyOprl.html

[7] DIBAVOD - Digitální báze vodohospodářských dat [online]. [cit. 16.srpna 2020]. Dostupné z: http:// www.dibavod.cz

[8] FORMAN, R. a GODRON, M. Krajinná ekologie. Praha: Academia, 1993. 1. vydání, 583 str. ISBN 80-200-0464-5.

[9] Databáze LUCC Czechia: Databáze dlouhodobých změn využití ploch Česka (1845-2010). Ivan Bičík a kolektiv, Prírodovědecká fakulta Univerzity Karlovy [online]. [cit. 18. srpna 2020]. Dostupné z: https:// lucccz.cz/databaze

[10] JECH, K. Soumrak selského stavu 1945-1960. Sešity Ústavu pro soudobé dějiny AV ČR. 2001/35.

[11] JELEČEK, L. Zemědělství a půdní fond v Čechách ve 2. pol. 19. století. Praha: Academia, 1985, 283 str.

[12] Mokřady [online]. [cit. 21. srpna 2020]. Dostupné z: http://www.mokrady.wbs.cz

[13] SKÅNES, H. Landscape change and grassland dynamics - Retrospective studies based on aerial photographs and old cadastral maps during 200 years in south Sweden. The Department of Physical Geography Stockholm University. Dissertation series, No. 8, papers I-IV, 1996, p. 12-14.

[14] RICHTER, P. a SKALOŠ, J. Sledování změn mokřadů v krajině nížin a pahorkatin České republiky 1843-2015. Vodní hospodáŕství, 2016, roč. 66, č. 8, s. 14-19.

[15] SKALOŠ, J., RICHTER, P. a KEKEN, Z. Changes and trajectories of wetlands in the lowland landscape of the Czech Republic. Ecological Engineering, 2017, 108, Part B, p. 435-445. ISSN 0925-8574.

[16] RICHTER, P. Mokřady na archivních mapových podkladech. Vodohospodárské technicko-ekonomické informace, 2020, roč. 62, č. 4, s. 30-37. ISSN 0322-8916.

[17] MOŽNÝ, M., TRNKA, M., VLACH, V., VIZINA, A., et al. Past (1971-2018) and future (2021-2100) pan evaporation rates in the Czech Republic. Journal of Hydrology, 2020, No. 519. ISSN 0022-1694.

[18] MIČANÍK, T., VYSKOČ, P., PRCHALOVÁ, H., POLÁŠEK, M. a kol. Hodnocení stavu útvarů povrchových vod v České republice pro 3. plánovací období. Vodohospodář́sé technicko-ekonomické informace, 2020, roč. 62, č. 6, s. 4-19. ISSN 0322-8916.

[19] GUY, P. et al. Full list of signatories to: Pe'er et al. „Action needed for the EU Common Agricultural Policy to address sustainability challenges" (Preprint version) [online]. [cit. 17. záŕí 2020]. Dostupné z: https://zenodo.org/record/3685632\#.X2MxkmgzaUk

[20] GUY, P. et al. Action needed for the EU Common Agricultural Policy to address sustainability challenges. People and Nature, 2020, No. 2, p. 305-316.

\section{Autor}

Ing. Pavel Richter, Ph.D.

凶 pavel.richter@vuv.cz

ORCID: 0000-0001-6338-3481

Výzkumný ústav vodohospodářský T. G. Masaryka, v. v. i.

Příspěvek prošel lektorským řízením.

DOI: 10.46555/VTEI.2020.09.003
THE TRAJECTORY OF WETLANDS DEVELOPMENT IN THE UPPER PART OF THE VÝROVKA RIVER BASIN OVER THE LAST 180 YEARS

\section{RICHTER, P.}

TGM Water Research Institute, p.r.i.

Keywords: archival maps - wetlands - GIS - landscape changes - water in landscape - agricultural management

The article is focused on analysis of the change of wetlands coverage and the representation of various types of wetlands in the upper part of the Výrovka river basin over the last 180 years. The historical maps of the Stable Cadastre, current orthophotographs and GIS layers of actual localization and classification of different types of land cover were used as data sources. Based on the available data four types of wetlands were distinguished: wet meadows, wet meadows with trees, swamps and waterlogged forests. However, waterlogged forests were found only in current map materials. The area of wetlands has dramatically decreased from 687.74 hectares in the years $1838-1841$ (7.53\% of the solved area) to 9.29 hectares in 2019 (0.1\%). While most area of the historic wetlands were covered by wet meadows (98.82\%), waterlogged forests and wet meadows (40.23\%, respectively $42.10 \%$ ) form the largest part of the current wetland. Half of the area of historic wetlands was transformed to arable land, therefore the changes are mainly attributable to increased agricultural production. The findings could be used in landscape planning with regard to the protection and management of wetlands. 